\title{
Analisis Minat Penggunaan Dompet Digital LinkAja dengan Pendekatan Technology Acceptance Model (TAM) di Bandung
}

\section{Analyzing the Intention to Use of Digital Wallet LinkAja with Technology Acceptance Model (TAM) Approach in Bandung}

\author{
Teguh Widodo \\ Program Studi Manajemen Telekomunikasi dan Informatika, Fakultas Ekonomi dan Bisnis, Universitas Telkom, Bandung \\ e-mail: teguhwi@telkomuniversity.ac.id \\ Sofia Fauziana Putri \\ Program Studi Manajemen Telekomunikasi dan Informatika, Fakultas Ekonomi dan Bisnis, Universitas Telkom, Bandung \\ e-mail: sofiafznptr@gmail.com
}

\begin{abstract}
The purpose of this study is to analyze the factors that influence the intention to use of digital wallets with an expanded approach of technology acceptance model by adding subjective norms and perceived security as exogenous variables. Subjective norms variable is hypothesized either directly or indirectly through the endogenous variables in TAM to influence intention to use, while perceived security variable is hypothesized to have a direct effect. The hypotheses that have been submitted forms a theoretical framework as structural equation model (SEM). Empirical data was collected through an online survey of 233 respondents who answered 23 questionnaire questions in full. The selection of respondents is determined by purposive-non-probability sampling approach from active users of LinkAja in Bandung whose population is not yet known. The software used to perform the statistical tests of informing that all indicators used meet the criteria of validity and reliability, the ten hypotheses submitted are all accepted based on the $t$-significance test and strong determining factor. The five TAM variables and their expansion have a positive and significant effect on the intention to use. The biggest influence of antecedent variables on the intention to use sequentially is subjective norms, perceived usefulness, attitude, perceived ease of use, and the smallest is perceived security. In increasing the intention to use, operators should prioritize on increasing subjective norms from prospective users, such as testimonials from role models about the ease of use, convenience, and attractiveness of the digital wallets.
\end{abstract}

Keywords: TAM, subjective norms, perceived security, intention to use, digital wallet.

\begin{abstract}
ABSTRAK
Penelitian ini bertujuan untuk menganalisis faktor-faktor yang mempengaruhi minat penggunaan dompet digital dengan pendekatan model penerimaan teknologi yang diperluas yaitu dengan menambahkan norma subjektif dan persepsi keamanan sebagai variabel eksogenes. Subjective norms dihipotesiskan mempengaruhi intention to use, baik secara langsung maupun tidak langsung yaitu melalui variabel endogen dalam TAM, sedangkan variabel perceived security dihipotesiskan berpengaruh langsung. Keseluruhan hipotesis yang diajukan membentuk sebuah kerangka penelitian dalam model persamaan struktural (SEM). Data empirik didapatkan melalui survei online terhadap 233 responden yang menjawab 23 butir pertanyaan kuesioner secara lengkap. Pemilihan responden ditentukan dengan pendekatan purposive-non-probability sampling dari pengguna aktif LinkAja di Bandung yang jumlah populasinya belum diketahui. Perangkat lunak yang digunakan untuk melakukan serangkaian pengujian statistik menginformasikan bahwa seluruh indikator yang digunakan memenuhi kriteria validitas dan reliabilitas, model penelitian memenuhi kriteria kecocokan, sepuluh hipotesis yang diajukan, seluruhnya diterima berdasarkan uji signifikansi-t, dan faktor determinasi yang kuat. Kelima variabel TAM dan perluasannya berpengaruh positif dan signifikan terhadap intention to use. Pengaruh terbesar variabel anteseden pada niat menggunakan berturut-turut adalah subjective norm, perceived usefulness, attitude, perceive ease of use, dan paling kecil adalah perceived security. Untuk meningkatkan minat penggunaan, para operator seyogyanya lebih memprioritaskan peningkatan subjective norms dari para calon pengguna antara lain berupa testimoni dari tokoh-tokoh panutan tentang kemudahan penggunaan, kenyamanan, dan daya tarik dompet digital tersebut.
\end{abstract}

Kata Kunci: $T A M$, norma subjektif, persepsi keamanan, minat penggunaan, dompet digital. 


\section{PENDAHULUAN}

Dalam beberapa tahun ke belakang, sistem pembayaran sudah berubah. Diawali dengan transaksi tunai maupun kartu kredit, menjadi beragam tipe sistem pembayaran digital menggunakan smartphone, yang kemudahannya sangat dimanfaatkan oleh pelanggan (de Luna et al., 2019). Menurut APJII (2020), pengguna internet di Indonesia didominasi oleh Pulau Jawa, dengan pengguna per provinsi secara berurutan oleh DKI Jakarta, Banten, Jawa Tengah, Jawa Barat, dan Jawa Timur. Sementara itu, berdasarkan ibukota provinsi secara berurutan ialah Serang, Jakarta, Surabaya, Bandung, serta Semarang dan Yogyakarta. Di sisi lain, financial technology sudah merambah di kalangan masyarakat Indonesia, dengan ditemukannya banyak pelanggan yang beralih dari transaksi tunai maupun kartu kredit ke transaksi digital. Penggunaan sistem pembayaran digital, khususnya dompet digital, sudah marak pada masyarakat Indonesia. Salah satu penerapannya dilakukan oleh Pemerintah Kota Bandung dengan meluncurkan program Bandung Cashless Payment dan Bandung Smart Card untuk mendukung transformasi sistem pembayaran dari tunai menjadi non-tunai (Humas Kota Bandung, 2018; era.id, 2018). Sebagai pemusatan pemerintahan dari Provinsi Jawa Barat, implementasi sistem cashless ini dapat menjadi evaluasi terhadap sistem cashless di Jawa Barat. Berdasarkan survei Ipsos (2020), alasan pelanggan dalam memilih dompet digital sebagai sistem pembayaran adalah karena kenyamanan yaitu berupa kepraktisan dan kemudahan penggunaan, promo, serta keamanan yang mencakup terdapat rekaman catatan transaksi (grid.id, 2020).

PT Fintek Karya Nusantara (Finarya) merupakan perusahaan yang bergerak di bidang penyelenggara jasa sistem pembayaran dengan produk dompet digital bernama LinkAja. LinkAja adalah layanan keuangan elektronik berbasis aplikasi dengan tujuan memberikan kemudahan dalam melakukan pembayaran, transfer uang, serta beli dan bayar beragam tagihan bagi penggunanya (LinkAja, 2021). Penggunaan aktual dompet digital LinkAja berada pada persaingan bawah dibandingkan kompetitornya yang secara berurutan yaitu ShopeePay, OVO, GO-PAY, dan DANA, berdasarkan survei yang dilakukan Ipsos (2020), salah satunya dipicu oleh rendahnya minat penggunaan. Peringkat tersebut disusun berdasarkan persepsi merek yang dinilai dari kemudahan, penawaran promo, dan pertumbuhannya. Selain itu, juga berdasarkan real time atau durasi jeda waktu antara pengisian saldo, kemudahan penggunaan atau user friendly, serta frekuensi penggunaan. Hal ini didukung dengan terdapat keluhan pengguna terhadap dompet digital LinkAja yang memiliki keterkaitan dengan indikasi rendahnya minat penggunaan dompet digital LinkAja beserta antesedennya. Keadaan tersebut sangat mungkin disebabkan oleh rendahnya norma subjektif pada pengguna yang apabila dibiarkan akan mempengaruhi munculnya sikap negatif, juga oleh rendahnya persepsi keamanan yang pada pengguna. Dari penjelasan tersebut, penelitian ini akan menunjukkan bagaimana jika perluasan Technology Acceptance Model (TAM) yang terintegrasi dengan Theory of Reasoned Action (TRA) dan Theory of Planned Behavior (TPB) sebagaimana yang dilakukan pada penelitian terdahulu milik de Luna et al. (2019) digunakan dalam menganalisis minat penggunaan suatu pembayaran digital.

Di sisi lain, studi mengenai Technology Acceptance Model (TAM) masih belum selesai. Masih banyak penelitian terdahulu yang menunjukkan bahwa Intention to Use sebagai variabel utama masih mengalami perkembangan pemikiran yang berasal dari faktor-faktor yang mempengaruhinya. Diperoleh celah penelitian berupa kontroversi mengenai beberapa faktor yang ternyata tidak berpengaruh terhadap Intention to Use, seperti Perceived Usefulness (de Luna et al., 2019; Liebana-Cabanillas et al., 2014), Attitude (de Luna et al., 2019), dan Perceived Security (de Luna et al., 2019). Melihat fenomena bisnis dan celah penelitian yang terjadi, perlu dilakukan penelitian lebih lanjut dan mendalam terhadap minat penggunaan dompet digital LinkAja untuk menambah wawasan, yang juga sejalan dengan tujuan penelitian ini yaitu untuk mengukur pengaruh dari determinan yang berkaitan dengan minat penggunaan dompet digital LinkAja melalui variabel-variabel yang dianalisis, yaitu Subjective Norms secara langsung dan tidak langsung, Perceived Ease of Use, Perceived Usefulness, Attitude, dan Perceived Security. Penelitian ini menunjukkan penjelasan terhadap kerangka pemikiran perluasan TAM terintegrasi yang diadopsi dari de Luna et al. (2019) terhadap penerimaan serta minat penggunaan dompet 
digital LinkAja pada pengguna, sehingga dilakukan pengujian ulang secara empirik antara pengaruh variabel-variabel tersebut terhadap intention to use, serta bagaimana peran variabelvariabel mediasi yaitu Perceived Ease of Use, Perceived Usefulness, dan Attitude dalam memperkuat pengaruh Subjective Norms terhadap Intention to Use secara tidak langsung.

\section{METODE PENELITIAN}

Penelitian ini merupakan penelitian kuantitatif, dengan analisis konklusif untuk menguji hipotesis dan kausal untuk menjelaskan hubungan sebab-akibat pada variabel dalam penelitian. Metode yang digunakan pada penelitian ini adalah Structural Equation Modeling (SEM) yang menggambarkan hubungan antar masing-masing variabel dalam bentuk persamaan struktural. SEM menjadi teknik analisis yang paling cocok digunakan apabila penelitian memiliki banyak variabel yang masing-masingnya direpresentasikan oleh beberapa indikator, dengan kategori variabel yaitu variabel eksogen dan variabel endogen (Hair et al., 2010). Variabel yang digunakan dalam penelitian ini terdiri dari variabel TAM beserta perluasannya, berupa variabel eksogen yaitu subjective norms dan perceived security yang tidak dipengaruhi oleh variabel lainnya, serta variabel endogen yaitu perceived ease of use, perceived usefulness, attitude, dan intention to use yang dipengaruhi oleh variabel lainnya. Uraian rinci keseluruhan variabel beserta indikator yang digunakan dalam penelitian dijelaskan pada Tabel 1 berupa operasionalisasi variabel.



Gambar 1. Kerangka Pemikiran

Penelitian ini mengadopsi kerangka penelitian de Luna et al. (2019) mengenai perluasan TAM dengan modifikasi yaitu satu hipotesis tambahan, di mana penelitian tersebut memiliki sembilan hipotesis sehingga terdapat total sepuluh hipotesis pada penelitian ini yang digambarkan pada Gambar 1. Penelitian mengenai Technology Acceptance Model (TAM) lanjutan dalam melihat penggunaan sistem pembayaran digital telah banyak dilakukan. Dalam mendukung penelitian milik de Luna et al. (2019), ditemukan pengaruh yang signifikan antara subjective norms terhadap perceived ease of use (Svendsen et al., 2013), perceived usefulness (Schepers \& Wetzels, 2007), dan intention to use (Jin et al., 2012, Martins et al., 2014). Selain itu, terdapat hasil bahwa perceived usefulness berpengaruh terhadap attitude (Hsu \& Chiu, 2004; Kim \& Shin, 2015), serta terhadap intention to use (Huang et al., 2013), yang bertolak belakang dengan hasil penelitian de Luna et al. (2019). Kemudian, penelitian terdahulu juga menunjukkan bahwa terdapat pengaruh yang signifikan antara perceived ease of use terhadap perceived usefulness (Liébana-Cabanillas, 2012; Muñoz-Leiva et al., 2012) dan attitude (Schepers \& Wetzels, 2007). Selain itu, terdapat pula penelitian yang menunjukkan bahwa attitude berpengaruh signfikan terhadap intention to use (Pavlou \& Fygenson, 2006; Schierz et al., 2010; Tsai et al., 2010) di mana bertentangan dengan hasil penelitian milik de Luna et al. (2019). Hal tersebut juga terjadi pada hasil penelitian de Luna et al. (2019) yang menunjukkan bahwa pengaruh perceived security 
tidak signifikan terhadap intention to use, yang bertolak belakang dengan hasil penelitian terdahulu bahwa perceived security berpengaruh signifikan terhadap intention to use (LiébanaCabanillas et al., 2018; Tarhini et al., 2016). Hal lain yang relevan dengan penelitian ini adalah minat penggunaan dompet digital LinkAja dipengaruhi secara langsung oleh rekomendasi individu yang dianggap penting, yang kemudian pengaruhnya diperkuat oleh beberapa hal lain, di antaranya kemudahan pengoperasian aplikasi, kebergunaan dan manfaat yang diperoleh berdasarkan transaksi, juga sikap pandang yang baik dan menganggap bertransaksi menggunakan LinkAja adalah bermanfaat. Oleh karena itu, penelitian ini juga mengasumsikan terdapat pengaruh tidak langsung signifikan antara subjective norms terhadap intention to use melalui variabel-variabel mediasi yaitu perceived ease of use, perceived usefulness, dan attitude yang memperkuat.

Berdasarkan referensi penelitian terdahulu yang mirip dan berhubungan mengenai sistem pembayaran digital, dirumuskan sepuluh hipotesis sebagai berikut.

H1: Subjective norms berpengaruh signifikan terhadap perceived ease of use pengguna LinkAja. H2: Subjective norms berpengaruh signifikan terhadap perceived usefulness pengguna LinkAja. H3: Subjective norms berpengaruh signifikan terhadap intention to use pada pengguna LinkAja. H4: Perceived usefulness berpengaruh signifikan terhadap attitude pengguna LinkAja.

H5: Perceived usefulness berpengaruh signifikan terhadap intention to use pengguna LinkAja.

H6: Perceived ease of use berpengaruh signifikan terhadap perceived usefulness pengguna LinkAja.

H7: Perceived ease of use berpengaruh signifikan terhadap attitude pengguna LinkAja.

H8: Attitude berpengaruh signifikan terhadap intention to use pengguna LinkAja.

H9: Perceived security berpengaruh signifikan terhadap intention to use pengguna LinkAja.

H10: Subjective norms berpengaruh tidak langsung signifikan terhadap intention to use pada pengguna LinkAja.

Tabel 1. Operasionalisasi Variabel






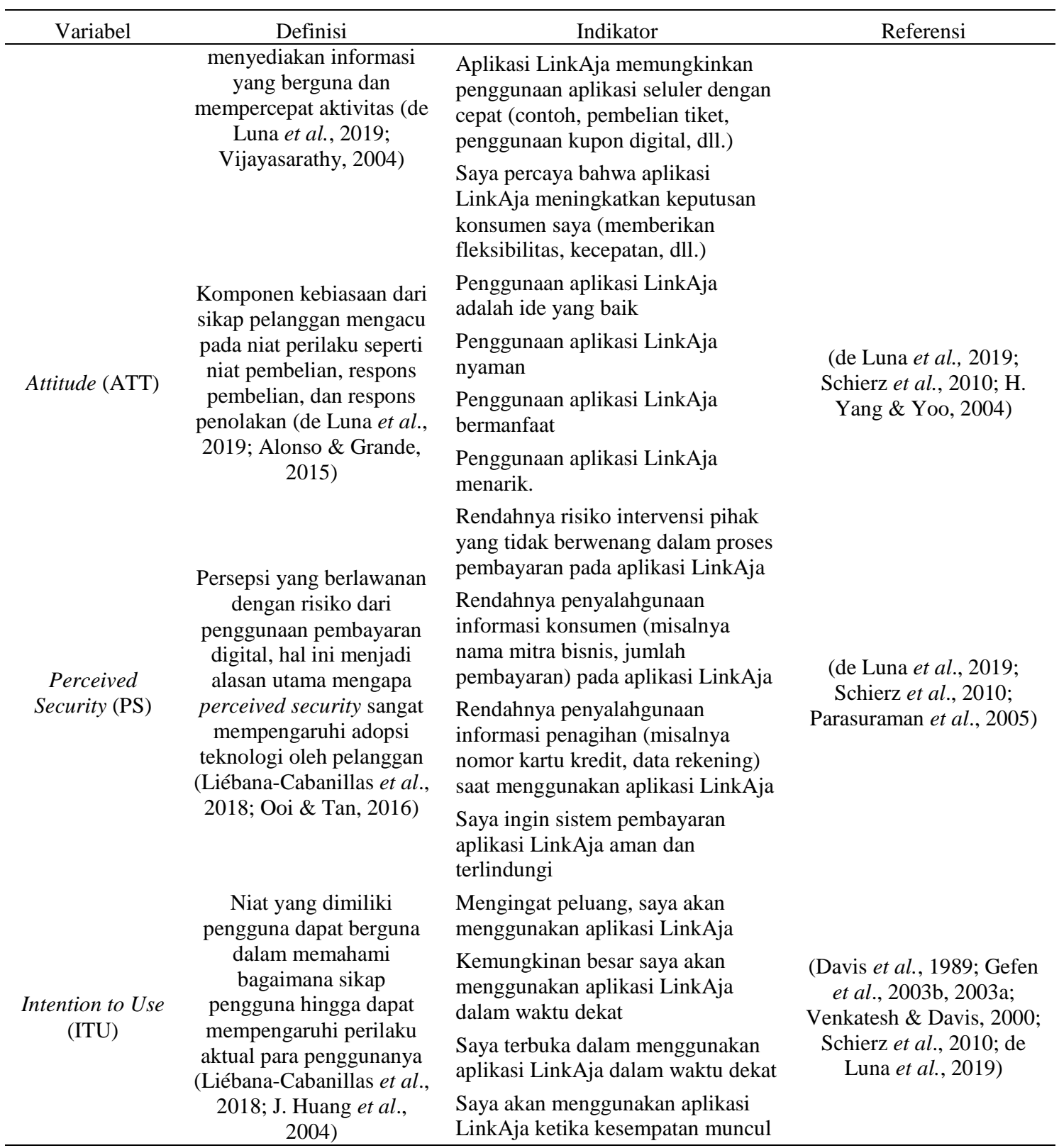

Dalam mengevaluasi kerangka pemikiran tersebut dan mencapai tujuan dari penelitian, dilakukan pengumpulan data berupa penyebaran kuesioner Google Form yang terdiri dari 23 butir pertanyaan yang merupakan indikator dari masing-masing variabel, terhadap orang-orang yang pernah bertransaksi menggunakan dompet digital LinkAja di Bandung. Skala perhitungan yang digunakan adalah skala ordinal Likert, dengan 1 "Sangat Tidak Setuju" sampai dengan 5 "Sangat Setuju". Penentuan sampel berdasarkan pendekatan purposive - non-probability sampling dengan tipe convenience sampling, yang berguna dalam mengambil sampel yang tersedia juga memungkinkan memberikan informasi bagi penelitian (Bryman \& Bell, 2011). Sampel yang diperoleh sebanyak 233 responden, sesuai dengan hubungan antara jumlah variabel dan ukuran sampel minimal dalam model struktural, di mana apabila terdiri dari enam sampai sepuluh variabel, maka ukuran minimalnya adalah 200 sampel (Bachrudin \& Tobing, 2003; Joreskog \& Sorbom, 1993). Data yang diperoleh dari kuesioner tersebut diolah menggunakan software LISREL 8.8 dalam menguji validitas menggunakan Average Variance Extracted (AVE) dan Confirmatory Factor Analysis (CFA) serta reliabilitas menggunakan Construct Reliability (CR) dari masing-masing indikatornya, selanjutnya menguji kecocokan model yang digunakan 
(Goodness of Fit), dan terakhir untuk menguji hipotesis yang telah dirumuskan menggunakan koefisien regresi dan nilai-T.

\section{HASIL DAN PEMBAHASAN}

\section{Uji Validitas dan Reliabilitas}

Dalam menguji validitas, penelitian ini menggunakan nilai Average Variance Extracted (AVE) dan Confirmatory Factor Analysis (CFA) yang dihitung dengan mengamati loading factor pada setiap indikator. Apabila nilai loading factor dan AVE lebih dari 0,5, dapat dianggap baik dan valid. Reliabilitas dapat dievaluasi menggunakan Construct Reliabilty (CR) yang dihitung menggunakan nilai loading factor. Suatu indikator dikatakan reliabel apabila bernilai di atas sama dengan 0,6, tetapi apabila di antara 0,5 dan 0,6 juga dapat diterima dengan catatatan memiliki validitas yang baik (Hair et al., 2010). Pada penelitian ini, seluruh indikator lolos uji validitas dan reliabilitas berdasarkan hasil perhitungan AVE dan CR dengan menggunakan loading factor. Perhitungan AVE dan CR dipaparkan pada Tabel 2.

Tabel 2. Hasil Uji Validitas dan Reliabilitas

\begin{tabular}{|c|c|c|c|c|c|}
\hline Variabel & Indikator & $\begin{array}{c}\text { Std. Loading } \\
\text { Factors }\end{array}$ & $\begin{array}{c}\text { Error } \\
\text { Variance }\end{array}$ & Construct Reliability & $\begin{array}{c}\text { Avg. Variance } \\
\text { Extracted }\end{array}$ \\
\hline \multirow{3}{*}{ SN } & SN1 & 0,88 & 0,23 & \multirow{3}{*}{ 0,93 (Reliabel) } & \multirow{3}{*}{0,82 (Valid) } \\
\hline & SN2 & 0,93 & 0,13 & & \\
\hline & SN3 & 0,91 & 0,16 & & \\
\hline \multirow{4}{*}{ PEU } & PEU1 & 0,84 & 0,29 & \multirow{4}{*}{ 0,91 (Reliabel) } & \multirow{4}{*}{0,73 (Valid) } \\
\hline & PEU2 & 0,84 & 0,29 & & \\
\hline & PEU3 & 0,87 & 0,25 & & \\
\hline & PEU4 & 0,86 & 0,26 & & \\
\hline \multirow{4}{*}{ PU } & PU1 & 0,84 & 0,29 & \multirow{4}{*}{ 0,93 (Reliabel) } & \multirow{4}{*}{ 0,77 (Valid) } \\
\hline & PU2 & 0,90 & 0,19 & & \\
\hline & PU3 & 0,91 & 0,17 & & \\
\hline & PU4 & 0,86 & 0,26 & & \\
\hline \multirow{4}{*}{ ATT } & ATT1 & 0,79 & 0,37 & \multirow{4}{*}{ 0,89 (Reliabel) } & \multirow{4}{*}{0,66 (Valid) } \\
\hline & ATT2 & 0,81 & 0,34 & & \\
\hline & ATT3 & 0,85 & 0,27 & & \\
\hline & ATT4 & 0,80 & 0,36 & & \\
\hline \multirow{4}{*}{ PS } & PS1 & 0,76 & 0,42 & \multirow{4}{*}{ 0,90 (Reliabel) } & \multirow{4}{*}{0,71 (Valid) } \\
\hline & PS2 & 0,87 & 0,25 & & \\
\hline & PS3 & 0,90 & 0,19 & & \\
\hline & PS4 & 0,84 & 0,30 & & \\
\hline \multirow{4}{*}{ ITU } & ITU1 & 0,87 & 0,23 & \multirow{4}{*}{ 0,95 (Reliabel) } & \multirow{4}{*}{0,82 (Valid) } \\
\hline & ITU2 & 0,93 & 0,12 & & \\
\hline & ITU3 & 0,91 & 0,16 & & \\
\hline & ITU4 & 0,91 & 0,16 & & \\
\hline
\end{tabular}

Keterangan: SN: Subjective Norms; PEU: Perceived Ease of Use; PU: Perceived Usefulness; ATT: Attitude; PS: Perceived Security; ITU: Intention to Use

\section{Uji Kecocokan Model (Goodness of Fit)}

Setelah mengevaluasi reliabilitas dan validitas dari indikator pengukuran, dibutuhkan pengujian kecocokan model menggunakan indeks dengan nilai batas yang telah ditetapkan untuk menunjukkan seberapa cocok model yang digunakan dalam merepresentasikan matriks kovarians pada indikator yang digunakan. Suatu model struktural dapat dikatakan cocok apabila memenuhi lima indeks pengukuran yang memiliki tingkat kecocokan Good Fit, sehingga model tersebut dapat dikategorikan cocok (Hair et al., 2010; Shara \& Widodo, 2018). Model struktural yang digunakan dalam penelitian ini tergolong ke dalam Good Fit atau cocok, dikarenakan memiliki lebih dari lima indeks dengan tingkat kecocokan Good Fit yang dipaparkan dalam Tabel 3. 
Tabel 3. Hasil Uji Kecocokan Model (Goodness of Fit)

\begin{tabular}{|c|c|c|c|}
\hline Goodness of Fit Indices & Cut-Off Value & Hasil Penelitian & Tingkat Kecocokan \\
\hline \multicolumn{4}{|c|}{ Absolute Fit Indices } \\
\hline$X^{2}$ Significance Probability & $\geq 0,05$ & $P=0,0$ & Poor Fit \\
\hline$G F I$ & $\geq 0,90$ & 0,82 & Marginal Fit \\
\hline RMSEA & $\leq 0,08$ & 0,079 & Good Fit \\
\hline$R M R$ & $\leq 0,08$ & 0,042 & Good Fit \\
\hline$S R M R$ & $\leq 0,08$ & 0,042 & Good Fit \\
\hline Nor. Chi-Square $\left(X^{2} / D F\right)$ & $<3$ & 2,238 & Good Fit \\
\hline \multicolumn{4}{|c|}{ Incremental Fit Indices } \\
\hline NFI & $\geq 0,90$ & 0,98 & Good Fit \\
\hline$T L I(N N F I)$ & $\geq 0,90$ & 0,98 & Good Fit \\
\hline$C F I(R N I)$ & $\geq 0,90$ & 0,98 & Good Fit \\
\hline$R F I$ & $\geq 0,90$ & 0,97 & Good Fit \\
\hline$I F I$ & $\geq 0,90$ & 0,98 & Good Fit \\
\hline \multicolumn{4}{|c|}{ Parsimony Fit Indices } \\
\hline$A G F I$ & $\geq 0,90$ & 0,78 & Poor Fit \\
\hline PNFI & $\geq 0,50$ & 0,85 & Good Fit \\
\hline$P G F I$ & $\geq 0,50$ & 0,66 & Good Fit \\
\hline
\end{tabular}

\section{Uji Hipotesis}

Setelah menguji kecocokan model, hipotesis penelitian yang telah dirumuskan sebelumnya diuji. Pada tahap ini, pengujian hipotesis baik langsung maupun tidak langsung dilakukan sambil mengembangkan sebuah model struktural. Dari model tersebut, dapat dibentuk persamaan struktural berdasarkan hubungan antar variabel yang terdapat dalam penelitian (Widodo \& Octaviany, 2019). Persamaan struktural pada penelitian ini dijelaskan dalam Tabel 4.

Tabel 4. Persamaan Struktural

\begin{tabular}{ccc} 
Persamaan & $\begin{array}{c}\text { Error Variance } \\
\text { (Errorvar. })\end{array}$ & $\mathbf{R}^{\mathbf{2}}$ \\
\hline $\mathrm{PEU}=0,88 * \mathrm{SN}$ & 0,23 & 0,77 \\
$\mathrm{PU}=0,26 * \mathrm{PEU}+0,68 * \mathrm{SN}$ & 0,15 & 0,85 \\
$\mathrm{ATT}=0,28 * \mathrm{PEU}+0,66 * \mathrm{PU}$ & 0,17 & 0,83 \\
$\mathrm{ITU}=0,24 * \mathrm{PU}+0,36 * \mathrm{ATT}+0,25 * \mathrm{SN}+0,17 * \mathrm{PS}$ & 0,057 & 0,94 \\
\hline
\end{tabular}

Persamaan pertama menunjukkan bahwa subjective norms berpengaruh besar terhadap perceived ease of use, dengan koefisien regresi senilai 0,88. Perceived usefulness dapat dijelaskan oleh subjective norms sebesar 77 persen, berdasarkan nilai $\mathrm{R}^{2}$ yang diperoleh. Sisanya ditujukkan oleh variabel lain sebanyak 23 persen berdasarkan nilai Error Variance. Persamaan kedua menjelaskan mengenai perceived usefulness dipicu oleh perceived usefulness dengan koefisien regresi sebesar 0,26 dan subjective norms dengan koefisien regresi senilai 0,68. Kedua variabel tersebut yaitu perceived ease of use dan subjective norms dapat menjelaskan perceived usefulness sebesar 85 persen, sesuai dengan perolehan hasil $\mathrm{R}^{2}$, dengan sisanya sebesar 15 persen dijelaskan oleh variabel lain sesuai dengan perolehan nilai Error Variance.

Persamaan ketiga menunjukkan bahwa perceived ease of use dan perceived usefulness mempengaruhi attitude sebesar masing-masing 0,28 dan 0,66 sesuai dengan koefisien regresinya. Attitude sendiri dapat dijelaskan oleh kedua variabel tersebut sebesar 85 persen berdasarkan perolehan nilai $\mathrm{R}^{2}$, dengan sisanya sebesar 17 persen dijelaskan oleh variabel lain berdasarkan perolehan nilai Error Variance. Persamaan keempat, menjelaskan bahwa perceived usefulness, attitude, subjective norms, dan perceived security sangat dapat memicu intention to use dengan kekuatan masing-masing sebesar 0,25, 0,36, 0,26, dan 0,17 sesuai dengan nilai koefisien regresi. Variabel-variabel tersebut sudah dapat menjelaskan intention to use sebesar 94 persen berdasarkan perolehan nilai $\mathrm{R}^{2}$, dengan variabel lain sebesar 5,7 persen berdasarkan perolehan nilai Error Variance.

Selain persamaan struktural, terdapat pengujian hipotesis yang ditentukan dengan

signsi menggunakan nilai-T beserta kekuatan hubungan antar variabel menggunakan nilai koefisien regresi untuk memperoleh jawaban dari pertanyaan penelitian. Suatu hubungan pengaruh dikategorikan signifikan apabila nilai-T yang diperoleh bernilai lebih dari nilai T-tabel 
yaitu 1,96 dengan interval keyakinan sebesar 95 persen (Shara \& Widodo, 2018; Widodo, 2015). Hasil pengujian hipotesis pengaruh langsung dan tidak langsung dipaparkan dalam Tabel 5 dan Tabel 6.

Tabel 5. Hasil Uji Hipotesis Hubungan Langsung

\begin{tabular}{cccc}
\hline Hipotesis Hubungan Langsung & Koefisien Regresi & T-Value & Hasil \\
\hline H1: SN $+\rightarrow$ PEU & 0,88 & 12,35 & H1 Diterima \\
H2: SN $+\rightarrow$ PU & 0,69 & 6,71 & H2 Diterima \\
H3: SN $+\rightarrow$ ITU & 0,25 & 2,47 & H3 Diterima \\
H4: PU $+\rightarrow$ ATT & 0,66 & 6,08 & H4 Diterima \\
H5: PU $+\rightarrow$ ITU & 0,24 & 2,21 & H5 Diterima \\
H6: PEU $+\rightarrow$ PU & 0,26 & 2,73 & H6 Diterima \\
H7: PEU $+\rightarrow$ ATT & 0,28 & 2,76 & H7 Diterima \\
H8: ATT $+\rightarrow$ ITU & 0,36 & 4,22 & H8 Diterima \\
H9: PS $+\rightarrow$ ITU & 0,17 & 2,92 & H9 Diterima \\
\hline
\end{tabular}

Sesuai dengan tujuan penelitian yang sebelumnya telah dirumuskan, bahwa seluruh hipotesis pengaruh langsung maupun tidak langsung diterima, di mana berarti hasil pengukuran masing-masing pengaruh antar variabel yang telah ditentukan adalah signifikan. Hipotesis 1, 2, dan 3, menjelaskan bahwa terdapat pengaruh yang positif dan signifikan antara subjective norms terhadap perceived ease of use, perceived usefulness, dan intention to use pada pengguna LinkAja. Saran yang diperoleh dari pihak penting di lingkungan sosial pengguna sangat mempengaruhi kemudahan penggunaan, kebergunaan, juga minat penggunaan dompet digital LinkAja. Hasil yang diperoleh ini memperkuat penelitian sebelumnya (de Luna et al., 2019; Svendsen et al., 2013; Schepers \& Wetzels, 2007; Jin et al., 2012; Martins et al., 2014). Oleh karena itu, baik dalam meningkatkan kemudahan pengoperasian pada pengguna maupun persepsi kebergunaan, dan kemudian meningkatkan minat menggunakan dan bertransaksi, LinkAja harus meningkatkan saran juga rekomendasi positif dari pihak yang berpengaruh besar pada lingkungan sosial, yang salah satunya dapat dilakukan dengan memperluas kerja sama dengan lembaga pemerintahan.

Selanjutnya, hubungan pengaruh antara perceived usefulness terhadap attitude dan intention to use pada Hipotesis 4 dan 5. Ditemukan bahwa perceived usefulness secara positif dan signifikan mempengaruhi baik attitude maupun intention to use pada pengguna LinkAja. Pengaruh ini menunjukkan bahwa kebergunaan sebuah sistem pembayaran memicu sikap dan niat pengguna terhadap menggunakan dompet digital LinkAja, yang bertolak belakang dengan hasil penelitian de Luna et al. (2019) tetapi mendukung beberapa penelitian terdahulu (Hsu \& Chiu, 2004; Kim \& Shin, 2015; Huang et al., 2013). Dalam meningkatkan sikap pandang pengguna agar melihat bahwa bertransaksi menggunakan LinkAja adalah ide yang baik, LinkAja harus meningkatkan persepsi kebergunaan, dengan cara antara lain menyediakan fitur yang lebih beragam dengan terus memaksimalkan kinerja layanan yang sudah tersedia. Hal tersebut juga dapat diterapkan dalam meningkatkan minat penggunaan untuk bertransaksi menggunakan LinkAja.

Terlebih lagi pada Hipotesis 6 dan 7 yang diterima, di mana terdapat pengaruh yang positif dan signifikan antara perceived ease of use terhadap perceived usefulness dan attitude. Kemudahan penggunaan sistem pembayaran sangat memicu kebergunaan suatu sistem serta sikap pandang pengguna terhadap dompet digital LinkAja. Hasil ini mendemonstrasikan bahwa kepentingan pengguna terhadap kegunaan serta sikap yang dirasakan dalam penggunaan dompet digital LinkAja, mendukung penelitian terdahulu de Luna et al., 2019; Liebana-Cabanillas, 2012; Munoz-Leiva et al., 2012; Schepers \& Wetzels, 2007). Persepsi kebergunaan serta sikap pandang yang dimiliki pengguna dapat ditingkatkan dengan secara bersamaan meningkatkan persepsi kemudahan. Meningkatkan persepsi kemudahan dapat dilakukan dengan cara antara lain LinkAja memperbaiki teknis kegagalan dan keterlambatan dalam bertransaksi, serta membuat tampilan layanan interaktif dan mudah dikenali serta dioperasikan.

Selain itu, Hipotesis 8, yang menjelaskan bahwa attitude memicu intention to use pada pengguna LinkAja, diterima. Sikap pengguna terhadap bertransaksi menggunakan dompet digital LinkAja sangat mempengaruhi minat penggunaannya. Hasil ini sesuai dengan penelitian 
terdahulu yang menjelaskan bahwa attitude berpengaruh besar terhadap intention to use (Pavlou \& Fygenson, 2006; Schierz et al., 2010; Tsai et al., 2010), walaupun terdapat juga penelitian terdahulu yang hasilnya bertolak belakang (de Luna et al., 2019). Untuk meningkatkan minat penggunaan, LinkAja harus meningkatkan penciptaan sikap pandang yang positif pada pengguna dalam bertransaksi. Hal ini didorong dengan dilakukannya peningkatan persepsi kebergunaan, yang antara lain dengan meningkatkan jangkauan fitur layanan serta memperkuat sistem agar pembayaran dengan LinkAja berjalan dengan lancar dan berhasil.

Kemudian, Hipotesis 9, mengenai perceived security yang berpengaruh signifikan terhadap intention to use pengguna LinkAja, diterima. Keamanan dalam bertransaksi menggunakan LinkAja berpengaruh besar terhadap minat penggunaan. Terdapat penelitian terdahulu yang bertentangan dengan hasil penelitian ini (de Luna et al., 2019), tetapi terdapat juga yang diperkuat oleh hasil yang diperoleh pada penelitian ini (Liebana-Cabanillas et al., 2018; Tarhini et al., 2016). Meningkatkan persepsi keamanan mampu memicu peningkatan minat penggunaan pada pengguna LinkAja, antara lain dengan bekerja sama dengan pihak profesional untuk memperkuat sistem jaringan dan meminimalisasi risiko yang dimiliki pengguna.

Tabel 6. Hasil Uji Hipotesis Hubungan Tidak Langsung

\begin{tabular}{c|c|c|c}
\hline Hipotesis Hubungan Langsung & Koefisien Regresi & $T$-Value & Hasil \\
\hline $\mathrm{H} 10: \mathrm{SN}+\rightarrow$ PEU $\rightarrow$ PU $\rightarrow$ ATT $\rightarrow$ ITU & 0,53 & 6,33 & H10 Diterima \\
\hline
\end{tabular}

Terakhir, Hipotesis 10, menjelaskan bahwa subjective norms berpengaruh tidak langsung signifikan terhadap intention to use, diterima. Berdasarkan hasil uji hipotesis, ditemukan bahwa variabel-variabel mediasinya yaitu perceived ease of use, perceived usefulness, dan attitude berperan memperkuat hubungan pengaruh tidak langsung tersebut. Oleh karena itu, selain dipengaruhi oleh variabel-variabel pada TAM, intention to use juga sangat dipengaruhi oleh variabel tambahan yaitu subjective norms, dengan perolehan pengaruh total sebesar 0,78 . Saran dari pihak penting pada lingkungan sosial sudah cukup mempengaruhi minat penggunaan dompet digital LinkAja, yang di dalamnya diperkuat oleh kemudahan interaksi dengan sistem pembayaran. Selain itu, penyediaan layanan yang bermanfaat dan mempercepat transaksi beserta sikap pandang terhadap sistem pembayaran dompet digital LinkAja juga memperkuat pengaruh tersebut. Pengguna yang memperoleh saran positif untuk bertransaksi menggunakan LinkAja memiliki kecenderungan peningkatan niat menggunakan, sehingga perlu ditingkatkan saran-saran dari pihak berpengaruh tersebut. Sambil meningkatkan norma subjektif tersebut, LinkAja juga harus melakukan peningkatan kemudahan penggunaan dan interaksi pada tampilan LinkAja, kemudian memperluas jangkauan fitur layanan LinkAja yang mampu mempercepat transaksi, dan juga membentuk suatu sikap positif bahwa bertransaksi dengan LinkAja adalah baik serta bermanfaat agar minat penggunaan juga ikut meningkat.

\section{KESIMPULAN}

Sebagaimana hasil statistik yang telah diperoleh, variabel paling penting dalam memicu intention to use ialah subjective norms. Hal ini didukung dengan ditemukannya pengaruh yang signifikan antara subjective norms terhadap perceived ease of use, perceived usefulness, dan intention to use pada pengguna LinkAja sehingga Hipotesis 1, 2, dan 3 diterima. Ini menunjukkan bahwa saran pihak penting dari lingkungan sosial sangat memicu kemudahan penggunaan, kebergunaan, serta minat penggunaan dompet digital LinkAja. Perceived usefulness juga merupakan faktor penentu penting yang berkaitan dengan intention to use. Pada kenyataannya, terdapat pengaruh yang signifikan antara perceived usefulness terhadap attitude dan intention to use pada pengguna LinkAja yang menunjukkan bahwa Hipotesis 4 dan 5 diterima. Pada kenyataannya, ditemukan bahwa sikap pandang pengguna terhadap penggunaan serta minat penggunaan dompet digital LinkAja pada penggunanya sangat dipicu oleh kebergunaan. Sementara itu, perceived ease of use juga cukup dapat mempengaruhi perceived usefulness serta attitude secara positif dan signifikan, sehingga Hipotesis 6 dan 7 diterima. Kemudahan penggunaan yang dirasakan oleh pengguna tentu dapat memicu kebergunaan serta sikap pandang 
yang dimiliki pengguna terhadap bertransaksi menggunakan dompet digital LinkAja. Attitude pun dianggap sebagai variabel penting dalam mempengaruhi intention to use. Berdasarkan hasil yang diperoleh, terdapat hubungan pengaruh yang signifikan antara attitude terhadap intention to use pengguna LinkAja yang menunjukkan bahwa Hipotesis 8 diterima. Hal ini menjelaskan perasaan maupun sikap dari pengguna untuk bertransaksi menggunakan dompet digital LinkAja sangat mendorong minat penggunaan para pengguna. Sama halnya dengan perceived security yang cukup dapat mempengaruhi intention to use, sehingga menghasilkan Hipotesis 9 diterima. Variabel yang tidak termasuk ke dalam TAM ini sudah seringkali digunakan dalam penelitian mengenai minat penggunaan suatu teknologi, di mana pada penelitian ini menunjukkan bahwa rendahnya risiko dalam bertransaksi menunjukkan kecenderungan yang lebih besar bagi pengguna untuk berminat menggunakan dompet digital LinkAja. Terakhir ialah adanya peran variabel-variabel mediasi yaitu perceived ease of use, perceived usefulness, dan attitude dalam memperkuat pengaruh antar subjective norms dan intention to use pada pengguna LinkAja, sehingga Hipotesis 10 diterima.

\section{DAFTAR PUSTAKA}

Alonso, J. R., \& Grande, I. E. (2015). Comportamiento del consumidor: Decisiones y estrategia de marketing. Esic.

APJII. (2020). Laporan Survei Internet APJII 2019-2020 [Q2]. APJII. https://apjii.or.id/survei

Bachrudin, A., \& Tobing, H. L. (2003). Analisis Data Untuk Penelitian Survai dengan Menggunakan Lisrel 8. Jurusan Statistika FMIPA-UNPAD.

Bhattacherjee, A. (2001). An empirical analysis of the antecedents of electronic commerce service continuance. Decision Support Systems, 32(2), 201-214. https://doi.org/10.1016/S01679236(01)00111-7.

Bryman, A., \& Bell, E. (2011). Business Research Methods. United Kingdom: Oxford University Press.

Davis, F. D., Bagozzi, R. P., \& Warshaw, P. R. (1989). User Acceptance of Computer Technology: A Comparison of Two Theoretical Models. Management Science, 35(8), 9821003. https://doi.org/10.1287/mnsc.35.8.982.

de Luna, I. R., Liébana-Cabanillas, F., Sánchez-Fernández, J., \& Muñoz-Leiva, F. (2019). Mobile payment is not all the same: The adoption of mobile payment systems depending on the technology applied. Technological Forecasting and Social Change, 146, 931-944. https://doi.org/10.1016/j.techfore.2018.09.018.

era.id. (2018, August 13). Bandung Menuju Kota Cashless. Era.id: Afair. https://era.id/afair/11134/bandung-menuju-kota-icashlessi.

Gefen, D., Karahanna, E., \& Straub, D. W. (2003a). Inexperience and experience with online stores: The importance of tam and trust. IEEE Transactions on Engineering Management, 50(3), 307-321. https://doi.org/10.1109/TEM.2003.817277.

Gefen, Karahanna, \& Straub. (2003b). Trust and TAM in Online Shopping: An Integrated Model. MIS Quarterly, 27(1), 51. https://doi.org/10.2307/30036519.

grid.id. (2020, November 6). Survei Ipsos in Indonesia: ShopeePay Jadi Dompet Digital dengan Pengguna Tertinggi. https://www.grid.id/read/042415950/survei-ipsos-in-indonesiashopeepay-jadi-dompet-digital-dengan-pengguna-tertinggi?page $=$ all.

Hair, J. F., Black, W., Babin, B. J., \& Anderson, R. E. (2010). Multivariate Data Analysis: A Global Perspective (7th ed.). Pearson Education Inc.

Hsu, M.-H., \& Chiu, C.-M. (2004). Internet self-efficacy and electronic service acceptance. Decision Support Systems, 38(3), 369-381. https://doi.org/10.1016/j.dss.2003.08.001.

Huang, J., Lee, B. C. Y., \& Hsun Ho, S. (2004). Consumer attitude toward gray market goods. International Marketing Review, 21(6), 598-614. https://doi.org/10.1108/02651330410568033. 
Huang, T. C.-K., Wu, I.-L., \& Chou, C.-C. (2013). Investigating use continuance of data mining tools. International Journal of Information Management, 33(5), 791-801. https://doi.org/10.1016/j.ijinfomgt.2013.05.007.

Humas Kota Bandung. (2018, February 14). Bandung Cashless Payment, Cara Transaksi Aman dan Nyaman. Humas Kota Bandung: Berita. https://humas.bandung.go.id/berita/bandungcashless-payment-cara-transaksi-aman-dan-n.

Ipsos. (2020). Evolusi Dompet Digital Menuju Keberlanjutan Bisnis (p. 26). https://www.ipsos.com/en-id/ipsos-media-conference-strategi-menang-tanpa-bakar-uang

Jin, D., Chai, K., \& Tan, K. (2012). Organizational adoption of new service development tools. Managing Service Quality: An International Journal, 22(3), 233-259. https://doi.org/10.1108/09604521211230978.

Joreskog, K. G., \& Sorbom, D. (1993). LISREL 8: Structural Equation Modeling with the SIMPLIS Command Language. Scientific Software International.

Kim, K. J., \& Shin, D.-H. (2015). An acceptance model for smart watches: Implications for the adoption of future wearable technology. Internet Research, 25(4), 527-541. https://doi.org/10.1108/IntR-05-2014-0126.

Liébana-Cabanillas, F. (2012). El papel de los sistemas de pago en los nuevos entornos electrónicos. Universidad de Granada.

Liébana-Cabanillas, F., Marinkovic, V., Ramos de Luna, I., \& Kalinic, Z. (2018). Predicting the determinants of mobile payment acceptance: A hybrid SEM-neural network approach. Technological Forecasting and Social Change, 129, 117-130. https://doi.org/10.1016/j.techfore.2017.12.015.

Liébana-Cabanillas, F., Sánchez-Fernández, J., \& Muñoz-Leiva, F. (2014). Antecedents of the adoption of the new mobile payment systems: The moderating effect of age. Computers in Human Behavior, 35, 464-478. https://doi.org/10.1016/j.chb.2014.03.022.

LinkAja. (2021, Januari). LinkAja. LinkAja. https://www.linkaja.id/.

Martins, C., Oliveira, T., \& Popovič, A. (2014). Understanding the Internet banking adoption: A unified theory of acceptance and use of technology and perceived risk application. International Journal of Information Management, 34(1), 1-13. https://doi.org/10.1016/j.ijinfomgt.2013.06.002.

Muñoz-Leiva, F., Hernández-Méndez, J., \& Sánchez-Fernández, J. (2012). Generalising user behaviour in online travel sites through the Travel 2.0.

Ooi, K.-B., \& Tan, G. W.-H. (2016). Mobile technology acceptance model: An investigation using mobile users to explore smartphone credit card. Expert Systems with Applications, 59, 33-46. https://doi.org/10.1016/j.eswa.2016.04.015.

Parasuraman, A., Zeithaml, V. A., \& Malhotra, A. (2005). E-S-QUAL: A Multiple-Item Scale for Assessing Electronic Service Quality. Journal of Service Research, 7(3), 213-233. https://doi.org/10.1177/1094670504271156.

Pavlou \& Fygenson. (2006). Understanding and Predicting Electronic Commerce Adoption: An Extension of the Theory of Planned Behavior. MIS Quarterly, 30(1), 115. https://doi.org/10.2307/25148720.

Schepers, J., \& Wetzels, M. (2007). A meta-analysis of the technology acceptance model: Investigating subjective norm and moderation effects. Information \& Management, 44(1), 90-103. https://doi.org/10.1016/j.im.2006.10.007.

Schierz, P. G., Schilke, O., \& Wirtz, B. W. (2010). Understanding consumer acceptance of mobile payment services: An empirical analysis. Electronic Commerce Research and Applications, 9(3), 209-216. https://doi.org/10.1016/j.elerap.2009.07.005.

Shara, P. V., \& Widodo, T. (2018). Penerapan Model Unified Theory Of Acceptance And Use Of Technology (UTAUT) Untuk Menganalisis Minat Pengguna Smartphone Di Kota Bandung. SOSIOHUMANITAS, 2O(1). https://doi.org/10.36555/sosiohumanitas.v20i1.49. technology acceptance: The influence of personality factors on the core constructs of the 
Technology Acceptance Model. Behaviour \& Information Technology, 32(4), 323-334. https://doi.org/10.1080/0144929X.2011.553740.

Tarhini, A., El-Masri, M., Ali, M., \& Serrano, A. (2016). Extending the UTAUT model to understand the customers' acceptance and use of internet banking in Lebanon: A structural equation modeling approach. Information Technology \& People, 29(4), 830-849. https://doi.org/10.1108/ITP-02-2014-0034.

Taylor, S., \& Todd, P. A. (1995). Understanding Information Technology Usage: A Test of Competing Models. Information Systems Research, 6(2), 144-176. https://doi.org/10.1287/isre.6.2.144.

Tsai, C.-H., Zhu, D.-S., Ho, B. C.-T., \& Wu, D. D. (2010). The effect of reducing risk and improving personal motivation on the adoption of knowledge repository system. Technological Forecasting and Social Change, 77(6), 840-856. https://doi.org/10.1016/j.techfore.2010.01.011.

Venkatesh, V., \& Davis, F. D. (2000). A Theoretical Extension of the Technology Acceptance Model: Four Longitudinal Field Studies. Management Science, 46(2), 186-204. https://doi.org/10.1287/mnsc.46.2.186.11926.

Vijayasarathy, L. R. (2004). Predicting consumer intentions to use on-line shopping: The case for an augmented technology acceptance model. Information \& Management, 41(6), 747-762. https://doi.org/10.1016/j.im.2003.08.011.

Widodo, T. (2015). The Effect of Transformative IT Capability on Sustainable Competitive Advantage. IEEE Xplore, 352-357. https://doi.org/10.1109/ICoICT.2015.7231450.

Widodo, T., \& Octaviany, V. (2019). The Effect of Culture-Based Culinary Tourism on Tourist Experience and Tourist Advocacy. International Journal of Engineering \& Technology, 8(1.9), 6. https://doi.org/10.14419/ijet.v8i1.9.26790.

Yang, H., \& Yoo, Y. (2004). It's all about attitude: Revisiting the technology acceptance model. Decision Support Systems, 38(1), 19-31. https://doi.org/10.1016/S0167-9236(03)00062-9. 